\title{
APLIKÁCIA INTERNETU A MOBILNÝCH TECHNOLÓGII V MARKETINGOVEJ STRATÉGII PODNIKU
}

\author{
Juraj Vaculík ${ }^{1}$, Lenka Trúchla ${ }^{2}$
}

\section{Úvod}

Elektronický marketing je v súčasnosti jedným z najrýchlejšie sa rozvíjajúcich odvetví hlavne z dôvodu neustáleho vývoja informačných technológií, neustále narastajúcich požiadaviek jednotlivca na ponúkané produkty a služby, jeho nároky na informovanost' a čoraz kratšiu časovú odozvu na požiadavky vo vzt’ahu zákazník - podnik.

Internet kombinuje vlastnosti bežných médií s možnost'ou okamžitej spätnej väzby. Tvorí sústavu vzájomne prepojených počítačových sietí, z ktorých každá patrí nejakému konkrétnemu subjektu. Každý používatel' môže využívat' prakticky všetky služby poskytované Internetom a prispievat' k jeho rozvoju. Pre podnik umožňuje oslovenie množstva potenciálnych zákazníkov, ktorí majú určitý záujem a nájdu si cestu k podniku, a ak budú chciet', môžu začat' komunikovat' s podnikom.

Pokial' firma dokáže integrovat' Internet plnohodnotne, môže ovplyvnit' svoju stratégiu, štruktúru riadenia, marketingovú komunikáciu, výrobky a služby. Podnik môže ušetrit' vel'a finančných prostriedkov a času investovaného do marketingových činností.

\section{Mobilný marketing}

Mobilný marketing je pojem, ktorý označuje jednu z metód priameho marketingu, založenú na využívaní mobilných zariadení, ako sú mobilné telefóny, smartphóny, PDA a zriedka prenosné počítače - notebooky. Na distribúciu komerčného či nekomerčného obsahu sa používajú technológie ako SMS, MMS, Bluetooth, WLAN, IRDA a iné.

Mobilný marketing sa skladá z rozličných foriem, medzi ktoré patrí SMS marketing, MMS marketing, Mobile Advertising, Mobile Marketing Research (marketingový prieskum s pomocou mobilných zariadení, či mobilný zber dát) a pod.

Stretávame sa s pojmami, ako je m-commerce, m-banking, m-wallet (mobilná peňaženka), m-pay (platenie cez mobil), m-security (bezpečnost' v mobilnom svete), mbroadcasting (živé vysielanie televízie či rozhlasu cez mobilné telefóny), Mobilný Internet, mbloging (mobilné blogovanie) atd'.

Od februára do marca 2008 bola uskutočnená anketa, zameraná na internetový a mobilný marketing mobilných providerov v SR. Dotazník bol poskytnutý 94 respondentom

\footnotetext{
${ }^{1}$ Doc. Ing. Juraj Vaculík, PhD., Žilinská univerzita, fakulta PEDAS, katedra spojov, vedúci oddelenia Elektronických komunikácií a služieb, mail: juvac@fpedas.uniza.sk

${ }^{2}$ Ing. Lenka Truchla, Žilinská univerzita, fakulta PEDAS, katedra spojov
} 
- vysokoškolským študentom univerzít na Slovensku. Pozostával z 19 otázok zameraných na ich osobné skúsenosti nielen s marketingovými aktivitami poskytovatel'ov mobilných telekomunikačných služieb, ktorých služby využívajú, ale aj s marketingom na Internete všeobecne. Ciel'om výskumu bolo zistit', aký majú respondenti názor na jednotlivé činnosti poskytovatel'ov mobilných služieb týkajúce sa oslovovania svojich zákazníkov prostredníctvom Internetu, mobilného telefónu, ako sú spokojní so svojim mobilným providerom, či ich oslovujú internetové reklamy a pod.

Dalšími otázkami výskumu boli otázky zamerané na webové stránky poskytovatel'ov mobilných služieb v SR. Ako jednotliví respondenti reagujú na dizajn, prehl'adnost' a jednoduchost' vyhl'adávania, či paletu výberu služieb poskytovaných elektronickou formou. Nešlo len o zistenie názoru na webovú stránku vlastného mobilného providera, ale aj na zvyšných dvoch.

Je zrejmé, že výsledky výskumu by sa od momentálnych výsledkov odlišovali pri inej skupine respondentov, napr. s inou vekovou štruktúrou. Respondentmi v tomto prípade boli študenti vysokých škôl na Slovensku, kde väčšina z nich sa nachádza v poslednom ročníku, t. j. skupina potenciálnych zákazníkov pre spoločnosti z dlhodobého hl'adiska. Je vel'ká šanca, že pokial' je študent so svojím poskytovatel'om spokojný a využíva len predplatené služby bez viazanosti, tak v prípade nástupu do zamestnania a pri možnosti stabilného príjmu bude jeho služby využívat' aj nad'alej. Vzniká tým určitá pravdepodobnost', že si zaobstará mesačný program s viazanost'ou, pokial' však nedôjde k lepšej alternatíve zo strany konkurencie.

Ked’že sa jedná o vzorku respondentov vo veku prevažne okolo 24 rokov, je relatívne vel'ký záujem o rôzne typy internetových sút'aží, v ktorých sa môžu stat' výhercami nejakej vecnej ceny a pod. Problematika reklamných bannerov podl'a výsledkov dotazníka je skôr pre respondentov nezaujímavá, t. j. nezáleží, aký druh reklamného banneru sa objaví na monitore, je skôr dôležité, aký obsah ponúka, resp. či je tento obsah pre užívatel'a podstatný a zaujímavý. Na druhu reklamného banneru záleží len 11\% respondentom. Preto je dôležité zamerat' sa na cielené druhy reklamy alebo iného druhu komunikácie, ktoré budú obsahovat' presne to, čo zákazníka zaujíma.

$\mathrm{Na}$ jednej strane by mal poskytovatel' mobilných služieb dbat' o svojho zákazníka prostredníctvom neustáleho informovania nielen cez bežné médiá, ale zamerat' sa individuálne na zákazníka cez modernú formu komunikácie, ktorou je Internet a mobilné zariadenia. Na druhej strane by mal mat' užívatel' pocit, že na trhu komunikačných služieb je široká paleta možností výberu a on nie je závislý len na výbere obmedzeného množstva. Firma by mala neustále aktualizovat' webové stránky, vyvíjat' služby poskytované prostredníctvom moderných distribučných kanálov, zabezpečit' možnost' objednania si služieb z pohodlia domova a pod. E-marketing tiež poskytuje oproti ostatným formám marketingu jedinečnú možnost' okamžitej spätnej väzby.

Uskutočnenie prieskumu bolo účelné nielen $\mathrm{z}$ dôvodu zistenia, ako respondenti reagujú na e-marketing, ale aj preto, aby boli zistené potrebné informácie pre uskutočnenie SWOT analýzy, ktorá sa nachádza vo štvrtej kapitole. Je zameraná na spoločnost' Telefónica O2, aby na základe konkrétnych zistení bolo možné určit' najefektívnejšie a najlepšie možné pôsobenie spoločnosti na trhu.

Spoločnost' je najmladším poskytovatel'om mobilných služieb v SR. Preto bola SWOT analýza aplikovaná práve na ňu. Z množstva silných, slabých stránok, príležitostí a hrozieb a na základe ich bodového ohodnotenia vznikla na tzv. Strategickej matici, ktorá je výsledkom SWOT analýzy, stratégia, ktorou sa spoločnost' uberá. 


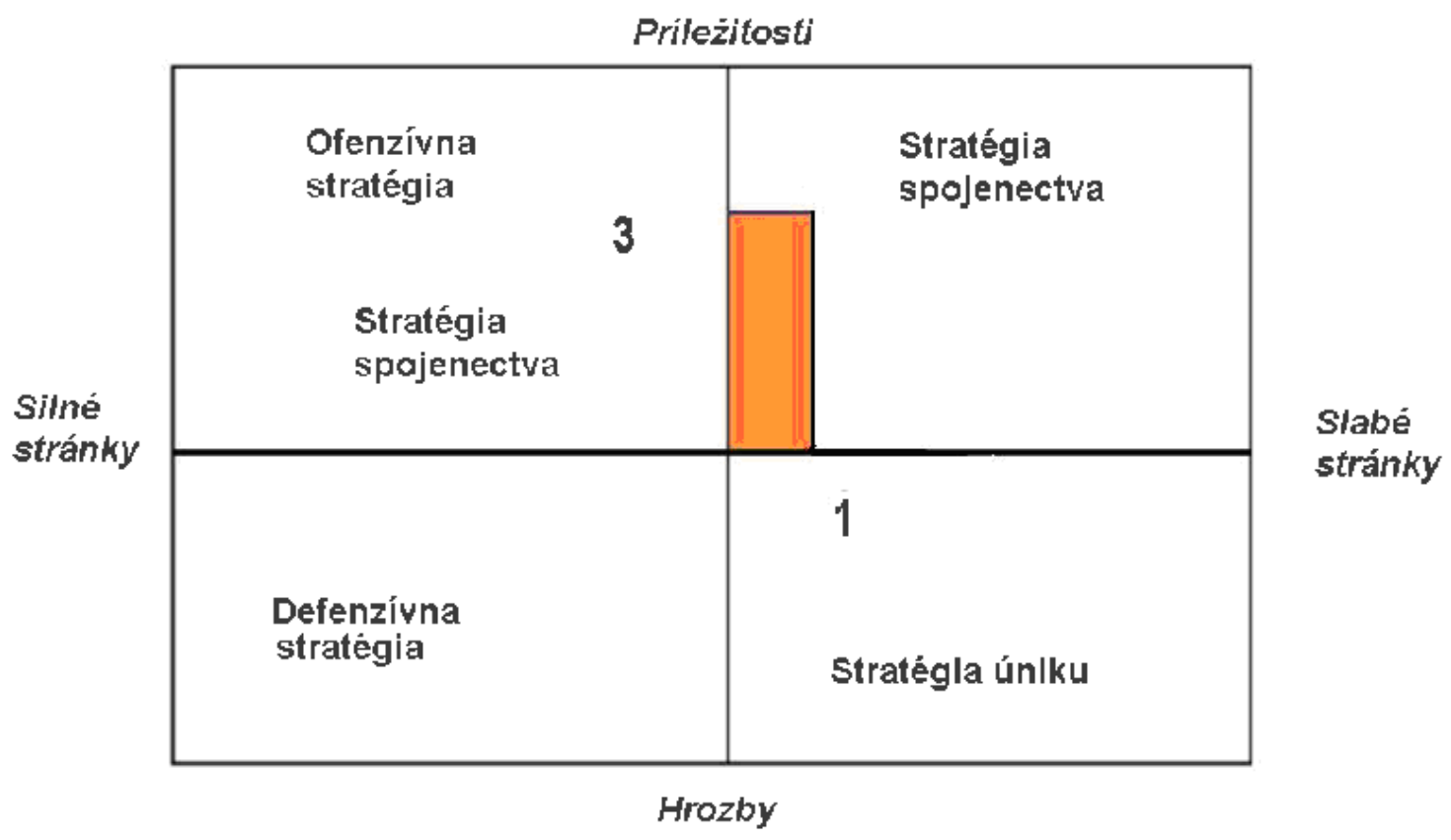

Obrázok 1. Strategický rozmer SWOT analýzy spoločnosti 02

Z bodového ohodnotenia vyplýva, že prevažujú slabé stránky nad silnými a v prípade externého prostredia prevažujú príležitosti nad hrozbami. Výsledná stratégia vznikla nanesením konečných ohodnotení do strategickej matice. Takto získaná stratégia predstavuje základné odporúčanie pre strategickú orientáciu podniku. Z grafického zobrazenia vyplýva, že spoločnost' by mala v budúcnosti uplatňovat' Stratégiu spojenectva. Spoločnost' sa nachádza na relatívne priaznivom trhu, kde na ňu pôsobí množstvo príležitostí, ktoré by sa mala snažit’ čo najlepšie využit' a na základe toho postupne eliminovat' slabé stránky, ktorých nemá až tak vela. Priaznivý trh v ponímaní internetového marketingu znamená, že existuje ešte vel'mi vel'a nevyužitých možností, vd’aka ktorým by sa spoločnost' mohla dostat' bližšie k svojim zákazníkom prostredníctvom moderných distribučných kanálov a technológií. Pokial' bude spoločnost' uplatňovat' túto stratégiu, t. j. neustále monitorovanie a využívanie príležitostí a potláčanie svojich slabých stránok, v budúcom období sa môže premiestnit' $\mathrm{k}$ Ofenzívnej stratégii, ktorá je pre postavenie podniku na trhu najvýhodnejšia.

\section{Silné stránky a možnosti ich posilnenia}

Zo zistených skutočností jednak z analýzy a jednak z výsledkov dotazníka alebo zo subjektívnych pozorovaní vyplýva, že najsilnejšou silnou stránkou by sa dalo nazvat' prevádzkovanie elektronického obchodu na webovej stránke spoločnosti. Táto silná stránka má aj vysoký efekt a dôležitost'. Prevádzkovanie elektronického obchodu je vel'mi dobrý spôsob, ako zvýšit' možnosti spoločnosti na získanie nových zákazníkov. Tento fakt by sa posilnil tým, že by ceny produktov, resp. služieb ponúkaných na Internete boli nižšie ako štandardne objednávané produkty alebo služby v predajniach alebo cez zákaznícku linku. Napríklad cena mesačného programu by bola nižšia o $10 \%$ bud' na určité obdobie alebo po celú dobu viazanosti.

Relatívne dobrá informovanost' zákazníkov spoločnosti môže priniest' pozitívne výsledky už len $\mathrm{z}$ toho dôvodu, že zákazníci sú $\mathrm{s}$ informáciami spokojní a je to pre nich pohodlné. Je dôležité udržat' si úroveň informovanosti na stabilnej úrovni, aby u zákazníkov 
spokojnost' neprerástla k neochote prijímat' informačné SMS alebo emaily z dôvodu ich častého prijímania.

\section{Slabé stránky a možnosti ich eliminovania}

Najsilnejšou slabou stránkou je absencia multifunkčnej webovej stránky v porovnaní s konkurenciou. $\mathrm{Na}$ webovej stránke absentuje vel'a výhod, ktoré ponúkajú konkurenční provideri. Neexistuje možnost' posielania SMS cez SMS bránu, sekcie pre nastavenia služieb, podobne ako u T-mobilu, zriadenie e-mailovej schránky a podobne.

K celkovému prospechu spoločnosti v komunikácií so svojim potenciálnym, ale aj bežným zákazníkom, prevažne zo segmentu študentov, prostredníctvom svojej webovej stránky, by prispelo vytvorenie neformálneho blogu, vktorom by sa mohli zákazníci vyjadrovat' o svojej spokojnosti, ale aj svoje negatívne názory. Spoločnost' by pre uvedením novej služby najskôr urobila menšiu anketu na blogu a spustila diskusiu o tom, či by sa zákazníkom konkrétny produkt pozdával alebo nie. Okrem toho by sa mohli zákazníci vyjadrovat' napríklad na tému reklamných kampaní, napísat' svoje požiadavky, návrhy a podobne. Takouto komunikáciou by sa mohla spoločnost' lepšie priblížit' požiadavkám zákazníkov.

Najmenej pôsobivá webová stránka je tiež jednou zo slabých stránok, ktoré spoločnost' má. Odstránenie tohto nedostatku však niekedy nie je jednoduché. Farebné zladenie, ktoré je použité na webovej stránke je spojené s logom a celkovou prezentáciou značky. Zmenit' prehl'adnost' stránky však nie je problém. Pokial' sa na stránku napríklad umiestni navigácia, resp. vyhl'adávanie, ul'ahčí to celkovú orientáciu zákazníka a prispeje k jeho spokojnosti.

\section{Príležitosti a hrozby a opatrenia s nimi spojené}

Nedajú sa nespomenút' niektoré príležitosti a hrozby, ktoré sú relatívne dôležité. Z uvedených príležitostí by mala spoločnost' využit' hlavne záujem o prijímanie reklamných správ na mobilný telefón za cenu vol'ných SMS, hovorov, či kreditu zadarmo. Táto príležitost' má najväčšiu závažnost' a pravdepodobnost' výskytu zo všetkých načrtnutých príležitostí. Spoločnost' by mohla na trh uviezt' osobitný mesačný program, resp. balík predplatených služieb, v ktorom bude každý zákazník prijímat' určitý počet reklamných správ od rôznych firiem pôsobiacich na Slovensku a za „odmenu“ dostane určitý počet vol’ných minút, resp. SMS alebo kredit na mesiac zadarmo.

Ked'že je spoločnost' na trhu v SR najkratšie, je to stále provider, ktorý môže priniest' na trh niečo nové, od ktorého sa podobné produkty alebo služby očakávajú. Pokial' sa bude neustále prispôsobovat' zákazníkom a ich požiadavkám, v d’alšom pôsobení a presadzovaní sa na trhu nebude zaostávat' za konkurenciou.

Vstup na trh pri takmer 100\% penetrácii mobilných telefónov - bola pre spoločnost' najsilnejšou hrozbou nielen preto, že trh mobilných služieb bol v štádiu nasýtenosti, ale aj preto, že konkurencia mala niektorých svojich zákazníkov zmluvne viazaných. Závažnost' sa dá čiastočne znížit' zameraním svojej ponuky medzi segment zákazníkov, ktorí nie sú zmluvne viazaní. Ďalšou podstatne silnou hrozbou je fakt, že konkurencia má trh zmapovaný natol'ko, že akákol'vek snaha $\mathrm{O} 2$ presadit' sa na trhu s niečím novým podnieti konkurenciu k vytvoreniu podobnej, resp. lepšej ponuky pre zákazníka.

Vd’aka nárastu telekomunikačnej kapacity a poklesu nákladov na osobný počítač nastal rýchly rozvoj informačných technológií, predovšetkým Internetu. Nastali zmeny v jednotlivých častiach činností a podnikania ako sú rezervácie, hudba, správy, software, vzdelávanie či financie. Ciel’om však aj nad’alej zostáva vybudovanie si vzt’ahu ku zákazníkovi a snaha o dosiahnutie tržieb. Technológie obmedzili a niekde úplne odstránili geografické limity. Marketingová komunikácia sa rozšírila domov i do práce. Je možné 
komunikovat' v globálnom meradle. Znížila sa cena za zverejnenie odkazu a získanie spätnej väzby. Odkazy už nemusia tvorit' len slová a statické obrázky, sú obohatené o audio a video. Vzrástla interaktívnost' nielen medzi predávajúcim a kupujúcim ale tiež medzi samotnými kupujúcimi, ktorí sa môžu podelit' o svoje skúsenosti napríklad na fórach.

S rozvojom Internetu a komunikačných technológií vznikli nové formy obchodovania. Kontakt so zákazníkmi a rýchlejšia komunikácia s distribútormi a dodávatel’mi na globálnej úrovni. Internet ako celosvetová siet' umožňuje rýchle prepojenie na vel'kú vzdialenost', čo v dnešnej dobe predstavuje spojenie za relatívne nízke náklady.

Aplikovanie elektronického marketingu do činností firmy môže priniest' v relatívne krátkom čase pozitívne výsledky. Jednak z hl'adiska ušetrenia času, nákladov, pracovnej sily, ale aj z dôvodu, že vd'aka interaktivite a globálnemu dosahu sa internet a mobilné technológie stávajú úspešnou formou komunikácie a zaručujú relatívne dobrú úroveň spätnej väzby.

Pôsobenie spoločnosti Telefónica O2 na Slovensku sa datuje od februára 2007. Svojich potenciálnych zákazníkov však začala oslovovat' už v druhej polovici roku 2006, ked' rozbehla marketingovú kampaň, ktorá sa niesla $\mathrm{v}$ mene niečoho nového, čo ešte na Slovenskom mobilnom trhu nie je. Vd'aka priamej a otvorenej komunikácii sa spoločnosti podarilo získat' dostatočne vel'a zákazníkov v relatívne krátkom čase. Ako prvá začala prevádzkovat' elektronický obchod na webovej stránke, začala uvádzat' ceny s DPH, čo bolo na trhu elektronických komunikácií dovtedy nemožné.

Napriek tomu, že ceny hovorov vo vlastnej sieti sú vel'mi nízke a cenová stratégia donútila aj konkurenciu znížit' ceny hovorov, zákazníci, ktorí sú viazaní u konkurencie, využívajú SIM kartu spoločnosti $\mathrm{O} 2$ ako alternatívu, t. j. sekundárnu možnost'. Jedným z problémov je aj relatívne stále vysoká cena za prenesenie čísla k inému providerovi.

Spoločnost' sa od začiatku svojho pôsobenia zameriavala na zákazníkov prepaidových služieb, t. j. predplatených kariet a až neskôr vytvorila ponuku mesačných programov pre fyzické osoby, po čase aj právnické osoby. Tým, že na trhu pôsobí ešte len niečo vyše roka a svoju kampaň začala tým, že stále prináša zákazníkom niečo nové, zákazníci to aj od nej očakávajú. Jednou z možností by bolo vytvorenie špeciálnych reklamných paušálov pre študentov vo veku do 26 rokov, ktorí by takúto možnost' akceptovali. Tým by Telefónica potvrdila myšlienku, pod ktorou sa prezentácia značky uskutočňuje už viac ako rok.

Ďalšou možnost’ou aplikácie nových technológií a tým zefektívnenie času zákazníka by bolo zavedenie možnosti zvyšovania kreditu prostredníctvom Internet bankingu, technológiou NFC, na získavanie potrebných informácií o mobilných telefónoch, st’ahovanie cenníkov, či iných elektronických letákov priamo v predajni bez obsluhy zamestnancov.

Oslovit' a zaujat' v súčasnosti segment zákazníkov mladšieho veku, prevažne študentov nie je l'ahká záležitost'. Spôsob komunikácie, akým je potrebné nadviazat' spojenie sa pomerne odlišuje od komunikácie so zákazníkmi vyššieho veku, či firemnými zákazníkmi. Najlepšia forma je oslovenie a komunikácia prostredníctvom Internetu a mobilného telefónu, pretože cielená reklama má u zákazníka väčší význam ako len obyčajný reklamný banner, ktorý sa objaví na monitore počítača. Pokial' sa však táto forma nepremení na nežiaduci spôsob oslovovania - SPAM, pretože to by malo presne opačný efekt.

Vytvorenie blogu, ktorý by neobsahoval nijaké oficiálne prvky, aké sú užívatel'ovi známe z prostredia iných médií, by mohlo rozbehnút' relatívne pozitívny ohlas. Forma diskusie, kde by každý mohol vyjadrit' svoje pozitívne a negatívne skúsenosti, pripomienky, návrhy a vedomie, že je o tieto názory záujem zo strany spoločnosti by mohlo byt' pozitívnym prínosom.

A prečo práve segment študentov? Predovšetkým preto, lebo vývoj informačných technológií spôsobil, že sa stali každodenným a bežným nástrojom komunikácie. Spojením 
tejto úvahy so známym príslovím - Čo sa v mladosti naučíš, v starobe ako by si našiel - sa pre firmu vytvára významný prúd možností. Spoločnost' sa do aplikovania internetu a mobilných technológií zapojila rýchlo a zatial' úspešne. Pokial' bude Telefónica O2 neustále vyvíjat' svoju ponuku služieb prostredníctvom informačných technológií a tým sa snažit' zjednodušovat' zákazníkovi jeho možnosti a popritom si vybuduje status nevtieravého, jednoduchého, lacného providera a použije všetky prostriedky na to, aby si tento status udržala, zákazníci budú so službami spokojní a konkurenčné produkty nebudú mat' pre zákazníka význam, t. j. nebude mat' ani dôvod pre zmenu providera.

\section{Záver}

Marketingový mix týkajúci sa tradičného marketingu, ktorý sa skladá zo známych 4P, sa v súvislosti so zameraním sa na zákazníka transformuje na $4 \mathrm{C}$, čo znamená, že produkt sa mení na hodnotu pre zákazníka (Customer Value), cena predstavuje zákazníkove náklady (Cost to costumer), distribúcia sa zmení na zákaznícke pohodlie (Convenience) a propagácia sa pretransformuje na komunikáciu so zákazníkom (Communication). Ked' podnik vezme do úvahy nasledujúce skutočnosti a zapojí k tomu informačné technológie, vzniká preň jedinečná možnost' uplatnenia sa na trhu.

Spoločnosti, ktoré poskytujú mobilné služby v SR sa tiež zapájajú do celého procesu aplikovania informačných a komunikačných technológií do marketingových aktivít. Predaj produktov prostredníctvom elektronického obchodu, marketingová komunikácia využitím mobilných zariadení, či Internetu, komunikácia so zákazníkom využitím moderných technológií sa stáva bežnou súčast'ou ich činností.

\section{Literatúra}

[1.] TRuCHLA L., Aplikácia internetu a mobilných technológií v marketingovej stratégii podniku, diplomová práca, Žilinská univerzita, KS 2007/08

[2.] KOTLER, P.: Marketing manažment. Victoria Publishing, Praha, 1998. ISBN 28-39386-246-3.

[3.] NÍZKA, H.: Priamy marketing. IURA EDITION, Bratislava, 2002, ISBN 80-89047-38-6.

[4.] MADLEŇÁK, R.: Elektronický obchod. Žilinská univerzita v Žiline, Žilina, 2004. ISBN 808070-192-X.

\section{Grantová podpora}

AV 4/2045/08 - Aplikácia technológie RFID pre vybrané poštové procesy na úrovni HSS VEGA 1/0149/10 - Difúzne procesy nových mobilných služieb a ich hodnotový ret’azec 